\title{
DESENVOLVIMENTO LOCAL, EMPREENDEDORISMO E "GOVERNANCA" URBANA: onde está o trabalho nesse contexto?
}

\author{
Simone Wolff
}

\begin{abstract}
O artigo questiona três concepções de políticas públicas que se apresentam hoje como propostas alternativas ao paradigma econômico neoliberal e à precarização do mercado laboral que veio em sua esteira: desenvolvimento local, empreendedorismo e governança urbana, tendo como objeto as empresas que compõem o Arranjo Produtivo Local de Tecnologia de Informação da região de Londrina (PR) , o qual se insere dentro das políticas públicas aqui problematizadas. Os dados coletados do MTE demonstram que essas empresas tendem a aportar as atividades rotineiras presentes nas cadeias de valor das grandes transnacionais do ramo, que são mais sujeitas às vulnerabilidades laborais postas pela mobilidade que o capital ganhou com a globalização da economia. Assim, diferente da perspectiva oficial que orienta essas políticas, os resultados remetem a indicadores de precarização já consensuais na literatura especializada sobre o tema: baixo grau (relativo) de escolaridade, salários em torno de 0,5 a um salário mínimo, e alto índice de rotatividade.
\end{abstract}

PALAVRAS-CHAvE: Desenvolvimento local. Empreendedorismo. Governança urbana. Arranjos Produtivos Locais. Precarização do trabalho.

\section{INTRODUÇÃO}

Pretende-se colocar em questão três concepções de políticas públicas voltadas para a geração de renda que, conjugadas, se apresentam hoje como respostas ou propostas alternativas à precarização laboral que veio na esteira do paradigma econômico neoliberal: desenvolvimento local, empreendedorismo e governança urbana. Essas noções ganharam relevância na literatura especializada a partir da década de 2000, quando os efeitos deletérios das políticas liberalizantes ao comércio exterior sobre o mercado de trabalho no país se tornaram mais evidentes e prementes. Desde então, assiste-se a reformulações substanciais na concepção de administração pública com impactos nas ações voltadas para a geração de emprego e renda, agora

* Doutora em Ciências Sociais. Professora do Departamento e do Programa de Pós-Graduação em Ciências Sociais da Universidade Estadual de Londrina - UEL. Líder do Grupo de Estudos de Novas Tecnologias e Trabalho - GENTT/CNPq.

ROD. C. G. CID, KM (380). Campus Universitário. Cep:86051990. Londrina - Paraná - Brasil. wolff.simone@gmail.com Agradeço ao meu orientando Leonardo Antonio Silvano Ferreira pelo auxílio na elaboração dos gráficos e tabelas utlizados neste artigo, durante a vigência de seu curso de Mestrado. marcadas por uma abordagem empreendedora que reorienta o projeto de desenvolvimento nacional para projetos de desenvolvimento local. É nesse contexto que as cidades emergem como lócus privilegiado de atuação dessas políticas.

De acordo com Telles (2007, p. 207):

[...] é o modo como a ordem das coisas é configurada, construída e descrita num plano de referência que desloca os termos do que está posto como "verdade" e "fato incontestável", e é nesse mesmo deslocamento que essas verdades e esses fatos incontestáveis se desfazem como tais para se refazerem num outro diagrama de relações [...] A força da crítica não está na retórica da denúncia da barbárie que hoje se instala no mundo. A potência da crítica se faz num parâmetro descritivo que desloca ou redefine a ordem das coisas e suas relações, permitindo, a partir daí, estabelecer uma pauta de questões que não podem mais ser resolvidas nos termos habituais e que abre, portanto, a fenda a partir da qual a imaginação crítica pode se mostrar fecunda.

É dentro desse espírito que se levanta a hipótese, ou "fenda", que será aqui desenvolvida. Ou seja, a de que a perspectiva empreendedora que vem norteando as atuais políticas públicas de desenvolvimento e geração de renda, paradoxal- 
mente, acaba por esconder processos de precarização do trabalho, uma vez que os microempreendimentos fomentados tendem a aportar, preponderantemente, as atividades presentes nas "franjas" das cadeias de valor das corporações transnacionais. Espera-se confrontar tal perspectiva a partir de um “outro diagrama de relações" que permita recolocar a figura do trabalhador no centro de tais políticas, de modo que ele volte a ser entendido como portador de direito à proteção social, já que, sob a pecha de microempreendedor, elas recaem sobre seus ombros não mais como direitos, mas como encargos. ${ }^{1}$

A mudança no paradigma de mercado de trabalho ora em tela reflete os processos de desindustrialização levados a cabo pela liberalização da economia, carreada pela introdução das políticas neoliberais no país em meados da década de 1990. A mobilidade proporcionada ao grande capital por essa conjuntura ensejou a transferência dos processos mais rotineiros das plantas produtivas das grandes corporações transnacionais para países periféricos, cuja força de trabalho é tradicionalmente mais barata e dócil. É esse fenômeno que explica o crescimento de ocupações com baixa exigência de qualificação, majoritariamente dentro do setor de serviços, causando inflexões quantitativas e qualitativas no perfil da classe trabalhadora.

Esse padrão de mercado de trabalho difere substancialmente daquele que vigorava nas décadas de 1970 e 1980, quando as políticas macroeconômicas no país eram orientadas pelo modelo nacional-desenvolvimentista, pois, a renda oriunda do trabalho era primordial e fundamental à sua manutenção. Nesse período, houve considerável geração de postos de trabalho, sendo que a maior parte dos rendimentos relativos "[...] resultava do somatório das ocupações com remuneração de até 1,5 salário mínimo e de mais de cinco salários mínimos mensais [...]" (Pochmann, 2012, p. 27).

Conforme Pochmann (2012, p. 30), em que pese o recrudescimento do trabalho formal no país,

${ }^{1}$ Como informa De Sena (2010, p.82) em sua pesquisa sobre microempreendimentos na América Latina, via de regra, tais encargos se colocam como uma "alternativa forçada” frente à atual precarização do mercado laboral formal. particularmente depois de 2004, com o aumento das exportações e perda relativa na participação das importações, 94,8\% dos postos de trabalho criados ou recriados se inserem na faixa salarial de até 1,5 salário mínimo. Em 2009, esse padrão salarial representava quase a metade do total de empregos formais no país, sendo que sua maior parte, 47,8\%, estava vinculada ao setor de serviços. Assim, contrariamente ao que o governo, intelectuais do mainstream e mídia oficial levam a acreditar, longe de essa recuperação representar uma mobilidade social rumo a uma "nova" classe média com potencial "microempreendedor", esses trabalhadores seriam mais bem analisados sob a categoria de “working poor", referente a ocupações que estão na base da pirâmide social, com rendimentos que giram em torno do salário mínimo (Pochmann, 2012, p. 30).

A partir desse entendimento, a reflexão aqui desenvolvida tentará seguir o caminho inverso daquele que vem pautando as atuais políticas governamentais, ou seja, pensar esse novo universo laboral como um campo que sustenta a atual fase de acumulação capitalista, em que as políticas públicas são instrumentalizadas em prol de uma perspectiva de livre iniciativa, a qual reitera, ao invés de dirimir, a precarização do mercado de trabalho oportunizada pela globalização da economia. Para tanto, tomou-se como objeto o caso do Arranjo Produtivo Local de Tecnologia de Informação da região de Londrina - PR (APL de TI), tendo em vista ser essa uma ação que se coloca dentro das políticas públicas que apostam no fomento da atividade empreendedora como um meio de incremento ao desenvolvimento das economias locais, isto é, dos estados e municípios (CEAPG/CENN, 2012).

A pesquisa contou com uma primeira parte relativa à revisão bibliográfica sobre o tema e uma segunda relativa ao levantamento de dados sobre o perfil da força de trabalho presente nas firmas do APL selecionado. Os dados foram de natureza quantitativa, coletados do site do Ministério do Trabalho e Emprego (RAIS/CAGED), e se referiam às seguintes variáveis: vínculos empregatícios formais, salário por segmento de atividade, escolari- 
dade, demissão e rotatividade. Esse percurso foi estruturado em três seções, sendo que em cada uma foram desenvolvidos os três eixos em torno dos quais se articulam as questões conceituais e conjunturais que podem explicar, pela perspectiva aqui assumida, o tripé que atualmente fundamenta as concepções e aplicações das políticas públicas de enfoque empreendedorista.

Na primeira seção, será discutido o contexto em que tais políticas emergem, ou seja, a nova configuração de cadeias produtivas e de criação de valor formatada pela liberalização da economia e, portanto, da nova divisão internacional do trabalho engendrada por essa reestruturação, que trouxe a necessidade de novas respostas institucionais concernentes ao modelo de desenvolvimento econômico do país (Tapia, 2005). Na segunda, serão apresentadas as relações entre as políticas públicas urbanas inspiradas na concepção de desenvolvimento local, que fundamentam a abordagem empreendedorista de mercado de trabalho atualmente adotada pelo governo brasileiro. Na terceira, será discutido o local do trabalho sob os contextos e análises apresentados nos itens anteriores, a partir do caso do APL de TI de Londrina (PR) e região. Ao final, espera-se revelar a gama de interesses que perpassam a formulação de tais políticas em sua relação com a atual fase de acumulação capitalista e, assim, reencontrar o lugar do trabalho nessa dinâmica.

DAS CONEXÕES ENTRE AS CADEIAS PRODUTIVAS GLOBAIS DE VALOR EA ABORDAGEM EMPREENDEDORADEDESENVOLVIMENTO

As convulsivas crises capitalistas que vêm assolando o mundo na atualidade decorrem do esgotamento do padrão de acumulação fordista, o qual levou ao limite a propensão à desvalorização e substituição da força de trabalho mediante a aplicação de capital fixo para a melhoria da produtividade, gerando, como efeito, o subconsumo que, por sua vez, conduz à famigerada crise de superprodução. Quando a crise de superprodução ocorre, outra crise se instala, a de sobreacumulação, ocasionada pela "falta de oportunidades de investimentos lucrativos" (Harvey, 2005b, p. 116). A saída para a primeira crise é a clássica busca de força de trabalho barata e novos mercados de consumo. Para a crise de sobreacumulação, a solução é a criação de uma demanda de bens de capital e de novos recursos produtivos, o que exige um contínuo movimento de abertura de novos mercados para o aporte do capital excedente emanado dos países de industrialização avançada (2005b, p. 116). Em outras palavras, ambas as crises exigem um novo movimento de expansão capitalista que se manifesta a partir de uma nova divisão internacional do trabalho.

Esse cenário foi arquitetado pelas políticas macroeconômicas de cunho neoliberal, assinaladas, especialmente, por dois carros-chefe: 1) a globalização financeira, que tende a concentrar os investimentos estrangeiros diretos (IED) nos países centrais, ampliando seus derivativos a tal ponto, que eles passaram a exercer influência decisiva sobre as políticas de desenvolvimento das nações; e 2) a reestruturação produtiva carreada pelas grandes empresas a partir da incorporação das tecnologias de informação (TIs), que permitem a descentralização dos seus processos e cadeias de produção em vários pontos do planeta, sem que seja necessário neles se sediarem e, portanto, absorverem suas vulnerabilidades e encargos locais (Pochmann, 2004).

Foi no bojo dessas políticas que se forjou um novo padrão de acumulação de capital no qual a inovação tanto de processos como de produtos e serviços se tornou a principal estratégia competitiva. Para enfrentar o novo mercado de consumo, as grandes companhias, outrora alicerçadas sobre um modelo piramidal e centralizador dos diversos processos necessários à sua produção, deram lugar a firmas enxutas e flexíveis, caracterizadas pela compressão dos níveis hierárquicos e pela generalização dos processos de terceirização, subcontratação, contratos temporários etc. Tal descentralização é mais adequada ao paradigma econômico contemporâneo uma vez que permite às grandes empresas abarcarem rápida e eficientemente novos mer- 
cados - tanto de trabalho como de consumo -, ao mesmo tempo em que, pelo suporte das TIs, as conecta em uma rede capaz de integrá-las e geri-las em tempo real.

Esse novo modelo de empresa transfonteiras exigiu uma nova forma de disposição dos postos de trabalho, o que incidiu diretamente no âmbito da divisão internacional do trabalho. O sistema linear, inspirado no modelo fordista de organização do trabalho, em que tanto os produtos como os serviços de apoio à sua fabricação eram realizados no interior de uma mesma planta, com postos de trabalho bem definidos e dentro de atividades extremamente padronizadas, funcionou bastante bem até meados dos anos 1970, quando a meta era a produção em série voltada para os mercados nacionais. Entretanto, com o acirramento da competitividade internacional e a diversificação do consumo encetada pela internacionalização da economia, a planta da fábrica teve de ser repensada. É assim que o sistema Toyota tornou-se mais adequado ao contexto do capitalismo contemporâneo, já que ele se fundamenta num modelo de planta em que os processos são horizontalizados sob a forma de células interdependentes, cuja relação se dá através de sistemas de informação.

Dessa forma, as unidades produtivas extrapolam os muros da fábrica, conformando-se como semiautônomas e podendo, assim, estabelecer relações mercantis mais imediatas com seus mercados de consumo, tornando-se mais aptas para suprir as crescentes variações do mercado globalizado. Ademais, tal arranjo possibilita amenizar eventuais efeitos negativos que uma unidade poderia exercer sobre as outras, permitindo que os gargalos de produção sejam detectados e resolvidos sem que haja interferências sistêmicas nos processos de produção em sua totalidade.

Foi assim que as antigas empresas multinacionais se transformaram em grandes grupos transnacionais que, de acordo com Pochmann (2004, p. 31-32), hoje compreendem o

[...] mundo inteiro como espaço relevante para suas decisões de investimentos e produção, provocando, por consequência, a reorganização do processo produtivo em grandes extensões territoriais, sobrepondo, inclusive, jurisdições nacionais.

Com isso, foi inaugurada uma nova divisão internacional do trabalho, calcada em um "multicolonialismo renovado" que, embora continue a ser diligenciado pelas grandes corporações, difere de outros momentos de expansão e readequação geográfico-territorial capitalista, visto que agora não se assenta mais nas chamadas vantagens comparativas, mas sim competitivas.

O termo "vantagens competitivas" refere-se a um novo léxico econômico atualmente utilizado para se diferenciar das teorias econômicas clássicas, que se apoiam na antiga concepção de "vantagens comparativas”, istoé, aquelas referidas à disponibilidade e custos dos fatores de produção (trabalho, matériasprimas e recursos naturais) de cada país e (ou) região (Dall'Acqua, 2003). A ideia de vantagem comparativa esteve em voga como política industrial no Brasil durante o período conhecido como desenvolvimentista (que vai de meados dos anos 1940 a meados de 1970), o qual supunha “[...] forte expansão estatal e ampla internacionalização do mercado interno.” (Pochmann, 2004, p. 57). Já o termo “vantagem competitiva” é atribuído aos

[...] recursos específicos do território, ou seja, as características históricas, culturais e sociais do ambiente em que as empresas se inserem e que são dinamizadas na proximidade geográfica entre atores, instituições e organizações locais, não sendo facilmente reproduzidas em outros lugares (Fuini, 2008, p. 48).

Em síntese, enquanto as vantagens comparativas fundamentavam um projeto de desenvolvimento calcado na noção de nação, em que o Estado exercia um papel primordial na promoção do aquecimento da economia interna por meio de gastos públicos e políticas que visavam a alavancar a homogeneização econômica regional, as vantagens competitivas partem de um raciocínio contrário, quer dizer, imputam primazia ao local sobre o nacional. Segundo essa perspectiva, as "vantagens competitivas locacionais" são entendidas como aquelas relacionadas a um ambiente oportuno à 
disseminação e incremento do conhecimento através do fácil acesso a ativos e serviços de apoio, bem como de ações que incentivem a cooperação entre empresas e poder público (BNDES, 2004). É a partir desse horizonte que regiões e municípios passam a ser vistos como "variáveis importantes no estudo da competitividade" (Fuini, 2008, p. 150).

Na verdade, o que está em tela é um novo tipo de relação entre centro e periferia no plano da divisão internacional do trabalho, que, diferentemente das fases anteriores de expansão do capitalismo, não se organiza primordialmente em torno da equação manufatura (centro) X matérias-prima (periferia), como no período colonial, ou bens de alto valor agregado + tecnologia avançada (centro) $\mathrm{X}$ manufatura (periferia), como ocorreu sob o desenvolvimentismo. A ênfase agora se dá a partir da relação tecnologia avançada + bens de alto valor agregado (centro) X manufatura e serviços coligados (periferia) (Pochmann, 2005, 2004). Com isso, desenha-se um novo projeto de desenvolvimento em que

[...] a equidade [regional] deu lugar ao conceito de eficiência econômica, o emprego passou a ser menos importante que a competitividade e o Estado se retirou de arenas estratégicas, ampliando as bases para a retomada de fluxos de capital internacional (Caiado; Ribeiro; Amorim, 2004, p. 67).

Éissoqueexplica oexpedientedeexternalização das cadeias produtivas e de valor das grandes corporações e o novo contorno que elas ganharam na atualidade. Favorecidas pela desregulamentação e isenção tributárias diligenciadas pela liberalização das fronteiras nacionais ao comércio exterior, as grandes corporações passaram a distribuir grande parte de seus processos a empresas fornecedoras e subcontratadas, não só nas regiões periféricas de seus países de origem, mas, sobretudo, nos países periféricos que, além de tradicionalmente oferecerem força de trabalho barata, passam também a ofertar menores custos trabalhistas mediante a flexibilização dos direitos laborais, bem como maiores incentivos fiscais e logísticos.

Assim, diferentemente das antigas multinacionais, as transnacionais caracterizam-se como “networks globais”, ou seja, firmas cujo espaço de atuação é o mundo, extraindo mais-valia de modo universal (Dall'Acqua, 2003). Para tanto, a disposição dessas empresas na forma de rede é crucial, pois isso lhes confere a flexibilidade e a mobilidade necessárias para atuar de forma global, ao mesmo tempo em que lhes permite centralizar o controle de seus processos e transações sem que precisem se fixar nos lugares em que atuam, obtendo, desse modo, a vantagem adicional de se livrar de encargos sociais pátrios (Alves; Wolff, 2008). Nunca é demais lembrar o papel fundamental das TIs para o gerenciamento desses processos.

Tal mobilidade, por sua vez, requer a criação de localidades com condições adequadas para receber os " $[\ldots]$ excedentes de capital monetário carentes de oportunidades para investimento produtivo e lucrativo" (Harvey, 2004, p. 34). Na medida em que essas estruturas exigem intervenção estatal e financeira, explica-se a formação dos chamados distritos industriais ou clusters. Essa conformação considera a forma pela qual cada unidade produtiva se organiza a fim de se manter em conexão com os processos globais de produção, tanto para a manutenção de sua competitividade como para angariar o amparo de órgãos públicos, ou de parcerias público-privadas (MDIC, 2012; DECOMTEC/FIESP, 2005).

Nos termos de Castillo (2008, p.41), tal enfoque supõe perspectivar esses vínculos a partir da noção de "processos completos de produção", ou seja, considerando-os não como unidades avulsas, mas como atividades integradas “[...] em processos de produção e de trabalho de que forma parte desprendida, externalizada ou subcontratada [...]", de modo que cada uma constitui um nexo dentro de um circuito complexo e integrado de atividades que envolvem desde a distribuição de insumos, processos e produtos até a comercialização das mercadorias.

Tal estratégia remete àquilo que Silver (2005) apontou como a busca das quatro soluções de que o capitalismo sistematicamente lança mão em momentos de crise, tanto de superprodução como de sobreacumulação, a saber: 
[...] a "solução espacial” (relocação geográfica da produção); a "solução tecnológica/organizacional" (a introdução de tecnologias para reduzir mão de obra e a reestruturação das organizações corporativas, o que inclui a expansão da terceirização e de relações trabalhistas contingentes); a "solução de produto" (o deslocamento do capital para novas linhas de produção, menos sujeitas à competição e aos conflitos); e a "solução financeira" (o deslocamento integral do capital da produção para as finanças e a especulação) (Silver, 2005, p. 12).

Essas soluções vêm ao encontro da noção de "processo completo de produção" de Castillo (2008), a partir da qual o autor demarca uma metodologia que contempla a análise das cadeias produtivas coevas, desde os centros dos quais suas redes se irradiam, traduzidos em ramos particulares da economia, bem como a maneira pela qual eles atuam na opção de desenvolvimento adotada pelos países e regiões onde elas se conectam ou pretendem se conectar. Entendem-se, desse modo, os processos de "especialização forçada" de determinados produtos a que as localidades são submetidas, os quais, longe de representar maior autonomia no seu desenvolvimento, anexa-as de forma subordinada através de atividades que demandam menor agregação de valor (Caiado; Ribeiro; Amorim, 2004).

Com isso, o grande capital desenha a paisagem do mundo de acordo com suas necessidades. Ainda segundo o autor, os requisitos (a) e
(b) são aqueles que mais interferem nas localidades, pois requerem a construção de uma infraestrutura física apropriada a receber os grandes montantes de capital excedentes, os quais demandam toda a sorte de serviços de utilidade pública, tangíveis e intangíveis, para se desenvolver, isto é, parques industriais, saneamento, energia elétrica, telecomunicações, transportes, armazenagem, escolas (educação, qualificação). ${ }^{2}$ Ocorre que, com a perda de controle dos fluxos de capitais estrangeiros por parte dos Estados, os investimentos outrora captados pela mediação dos governos centrais também se liberalizam. Assim, cada vez mais, tal captação prescinde da intervenção estatal e passa a ser realizada mediante negociação direta entre poder local, público e privado, e o capital financeiro internacional (Harvey, 2006).

É isso que tem levado as gestões públicas municipais a deixarem de se orientar, ou de esperar pelos fomentos provenientes das administrações centrais, optando por uma investida "empreendedora" na condução de suas políticas de desenvolvimento, o que esclarece o surgimento das numerosas parcerias público-privadas nos últimos anos. Com efeito, essa é a abordagem que atualmente fundamenta as concepções de desenvolvimento local:

A construção de redes que visam fortalecer as ligações entre as formas intermediárias de coordenação constitui-se na própria essência do desenvolvimento econômico local [...] As redes são expressão das formas de ajustamento entre restrições extraterritoriais e as relações territoriais e nesse sentido a própria condição para o desenvolvimento local (Muls, 2008, p. 11).

Por isso, a metodologia aqui considerada parte da análise da forma pela qual cada localidade organiza sua produção a fim de se manter em conexão com as cadeias globais de produção e valor para assegurar a manutenção de sua economia, bem como o amparo dado por órgãos públicos, ou realizado em parceria público-privada, para facul-

${ }^{2}$ Isso, inclusive, esclarece em grande medida a necessidade e efetivação dos processos de privatização que vieram na esteira do neoliberalismo. 
tar essa estratégia. É essa visão que se pretende problematizar a seguir.

\section{DAS CONEXÕES ENTRE DESENVOLVIMENTO LOCAL, EMPREENDEDORISMOE GOVERNANÇA URBANA}

Entende-se por políticas públicas sociais aquelas que regulamentam, por intermédio do Estado, o modo de reprodução das classes trabalhadoras (Soldano; Andrenacci, 2005). São três as esferas de atuação dessas políticas, quais sejam, as de cunho assistencial (tais como o Programa Bolsa Família e Bolsa Escola no Brasil), as de serviços universais (como acesso à educação, saúde, saneamento básico etc.), e as relativas ao emprego, que visam a regulamentar o mercado de trabalho no sentido de garantir sua (re)qualificação e renovação ou perpetuação.

Até recentemente, essas últimas políticas voltavam-se para a garantia das conquistas trabalhistas legadas pelo padrão fordista de mercado laboral, ou seja, aquelas estabelecidas com base em um contrato formal de trabalho, por tempo indeterminado e seguridade social, tanto dentro como fora da esfera da produção. Com as mudanças trazidas pelas políticas neoliberais, sobretudo aquelas ocasionadas pelos processos de privatização das instituições reprodutivas da força de trabalho (referentes à educação, previdência, sistemas de saúde etc.), observa-se uma remercantizilização desses tipos de serviços, que antes estavam nas mãos ou sob a tutela do Estado, e cujas fontes de financiamento eram os encargos trabalhistas, dentre outros impostos voltados para as classes empresariais. As privatizações secaram essa última fonte, o que obrigou tais políticas a virarem a página do paradigma fordista de mercado e de trabalho, de maneira a adequarem-se à era do capitalismo flexível.

No Brasil, essa inflexão começou a ocorrer nos anos 1990, e teve a ver com a quebra dos monopólios das empresas estatais e a abertura comercial, que inauguraram um quadro de intensa competitividade entre as grandes empresas. A res- posta foi o estabelecimento de um novo "regime de acumulação financeirizada", no qual os investimentos são dirigidos primeiramente para o mercado de capitais, transformando os grandes grupos transnacionais "nos principais agentes microeconômicos" da economia nacional (Fiori, 2001, p. 120-121, grifo do autor).

Desde então, os governos vêm adotando como sistemática o controle das taxas de inflação em prol da elevação da taxa de juros, como forma de atrair investimentos estrangeiros e garantir o aquecimento da economia, o que acaba acarretando um continuado desequilíbrio nas contas públicas. Sem o suporte das grandes empresas estatais e diante da queda contínua das receitas fiscais em virtude do arrocho salarial e das políticas de isenção tributária às grandes empresas (medida também recorrentemente utilizada para atraí-las ao espaço nacional), a saída encontrada foi se inserir no novo regime de acumulação e transformar os déficits públicos em ativos financeiros (Fiori, 2001). Essa dinâmica levou a uma drástica redução dos investimentos governamentais voltados para o setor industrial, em favor do grande capital financeiro internacional, gerando estagnação da economia e ocasionando uma ruptura com relação ao modelo de desenvolvimento anterior, no qual o crescimento econômico era baseado na criação de postos de trabalho formais com salários compatíveis ao incremento do mercado nacional.

Nessas circunstâncias, as políticas de desenvolvimento regional quase desaparecem, reduzindo-se à estratégia de tornar os espaços urbanos e seus mercados de trabalho também fonte de especulação. A ideia é: "ganha” mais a cidade que oferecer melhores infraestruturas produtivas, maiores benefícios ou isenções fiscais e um mercado de trabalho qualificado no que se refere aos serviços de apoio à produção e ao consumo, porém mais barato relativamente a outras regióes e, não menos importante, sem tradição de conflitos trabalhistas. É desse modo que a "[...] guerra fiscal tornou-se o principal fator capaz de alterar as vantagens locacionais existentes entre as várias regiões" (Caiado; Ribeiro; Amorim, 2004, p. 70). Dentre elas, 
encontram-se as regulamentações trabalhistas que, cada vez mais, passam a ocorrer nos locais de trabalho, em detrimento dos acordos nacionais, borrando as fronteiras entre o trabalho formal e o informal e tornando oportuno o discurso do empreendedorismo urbano e individual (Portal do .../MDIC, 2012).

Assim, a mencionada ênfase na atratividade financeira acaba por facultar a volatilidade dos investimentos externos, tornando vulneráveis as fontes de emprego e, por conseguinte, o mercado de trabalho ao cassino global. Longe de alavancar um desenvolvimento autônomo e sustentável, essa situação tem levado os governos municipais a apostarem no embelezamento e "gentrificação"3 de suas cidades, de modo a passar uma imagem de "cidade global”, preparada a acolher o capital externo e a frutificar seus investimentos (Telles, 2007, p.204). Ocorre que a concorrência agora estabelecida em âmbito local acaba por tornar essas "cidades globais” verdadeiras “cidades genéricas” (idem), padronizadas tal qual um shopping center (Harvey, 2006). No final das contas, o que vai diferenciá-las e, assim, garantir a permanência ou conexão do grande capital no seu território são os incentivos e as isenções tributárias, bem como as subvenções ao mercado de consumo, principalmente de alto padrão, e às atividades e serviços que podem servir de subsídio aos seus negócios.

Esse contexto impele as políticas públicas de desenvolvimento a atuarem de modo semelhante, ou seja, a se estabelecerem como medidas atra-

Gentrificação é um termo utilizado pelos estudos urbanos para designar um processo de nobilitação de espaços metropolitanos deteriorados com vistas à sua ocupação pelas classes de maior poder aquisitivo (Wacquant, 2010 Harvey, 2006). Segundo Wacquant (2010, p.52, grifos do autor), tal fenômeno vem ao encontro de um novo conceito de desenvolvimento urbano fundamentado num "[... modelo mais amplo de invisibilidade da classe operária na esfera pública e na investigação social ao longo das últimas duas décadas [...] " que causa uma "obliteração literal e figurada do proletariado na cidade". Para o autor, essa leitura incita "[...] o papel em transformação do Estado, de provedor de assistência social para populações de renda mais baixa a fornecedor de serviços e amenidades empresariais para urbanitas de classe média - e alta - principalmente, entre eles, a limpeza, no ambiente construído e nas ruas, dos detritos físicos e humanos engendrados pela desregulação econômica e o corte de gastos de bem-estar social, de modo a renovar a cidade como local aprazível de e para o consumo burguês” (Wacquant, 2010, p.52, grifos do autor). tivas ao grande capital. É em consequência disso que ocorre a tendência à concentração de oferta de produtos e, sobretudo, de força de trabalho de baixo valor agregado, particularmente no setor de serviços (Pochmann, 2012), que hoje representa as franjas das cadeias de valor das transnacionais (Baltar; Wolff, 2009). Não é à toa que, no final da década de 1990, a participação dos investimentos estrangeiros diretos declinou consideravelmente no setor industrial, na mesma medida em que cresceu no setor de serviços. Em 1997, os IEDs relativos ao setor industrial foram da ordem de $13,3 \%$, enquanto que o setor de serviços aportou 83,7\% (Caiado; Ribeiro; Amorim, 2004).

É no marco dessa conjuntura que surgem e se disseminam, especialmente a partir da década de 1990, as concepções que norteiam a noção de desenvolvimento local como uma alternativa à crescente degradação do emprego formal. Essa perspectiva de desenvolvimento foi inspirada nas bem sucedidas experiências da chamada Terceira Itália, que, nos anos 1980, revigoraram economias de regiões que se colocavam à margem das grandes cadeias de produção europeias, através do engajamento de pequenos empreendimentos em torno de projetos comuns com o escopo de estimular os setores econômicos tradicionais. Essas estratégias logo começaram a influenciar a formulação de novas políticas públicas de geração de renda como uma resposta aos desafios colocados às economias nacionais pela globalização da economia e a consequente transnacionalização das grandes empresas (Tapia, 2005).

O desenvolvimento local se embasa nos chamados pactos territoriais, que

[...] trouxeram uma inovação institucional e de procedimento, na medida em que foram concebidos como um instrumento de intervenção pública descentralizada, ancorado em uma forte cooperação entre o governo, as regiões e as províncias autônomas, para o estabelecimento de objetivos comuns de maneira conjunta e para a escolha dos setores econômicos a serem estimulados (Tapia, 2005, p.135).

No que tange às políticas de geração de renda, seu fundamento principal é a substituição de medi- 
das entendidas como anacrônicas e assistencialistas em relação à força de trabalho, por estratégias embasadas na noção de "empreendedorismo" (Portal do.../MDIC, 2012). É desse modo que as pequenas e microempresas, geralmente de capital regional e (ou) municipal, ganham destaque. Dentro dessa perspectiva empreendedora de desenvolvimento:

Um importante ator do desenvolvimento econômico local são as micro e pequenas empresas. Estas podem desempenhar um papel importante e acionar um processo de desenvolvimento endógeno a partir do momento em que elas se organizem em redes e, além disso, que essas redes estejam articuladas com outras formas intermediárias de coordenação que, juntas, representam o ambiente institucional de um território ou região. Quanto maior é o grau de coesão das redes (sociais e econômicas, formais e informais) entre as formas intermediárias de coordenação, que se manifestam essencialmente no plano territorial, maior é o estoque de capital social ${ }^{4}$ deste território e maiores serão as chances de sua estratégia de reação autônoma redirecionar, a seu favor, as forças que emanam da pressão heterônoma (Portal do... /MDIC, 2012, p. 20).

Segundo essa concepção, portanto, a concentração de empresas de pequeno porte de uma mesma cadeia produtiva leva à formação de distritos industriais ou clusters que tornam mais fácil a obtenção de apoio estatal e financeiro. Via de regra, o primeiro é requerido para cavar incentivos aos investimentos pecuniários, agora oriundos preponderantemente do setor privado. Nesse sentido, a chave para a compreensão da interseção entre cadeias produtivas e as mencionadas políticas públicas de desenvolvimento local parte da ideia de que elas agenciam "[...] estruturas de comando (governance) em que uma ou mais empresas coordenam e controlam atividades econômicas geograficamente dispersas [...]", de modo a conectá-las àquelas “[...] que são estratégicas e que agregam mais valor [...]” (Dall'Acqua, 2003, p. 94).

É nesse sentido que as localidades ganham relevância, pois passam a ser percebidas como aquelas que comportam os aportes necessários a esse processo, uma vez que ali residem os liames

${ }^{4}$ O conceito de “capital social” será apresentado mais adiante. que podem propulsionar melhorias e inovações mais condizentes com as particularidades dos seus mercados de trabalho e consumo, além de encurtar o tempo de giro das mercadorias e, com isso, do capital. É isso que leva Dall'Acqua a afirmar que o atual padrão de desenvolvimento “[...] parece depender muito da capacidade política das instituições nacionais e supranacionais para impulsionar a estratégia de crescimento desses países ou regiões sob sua jurisdição" (2003, p. 52, grifo da autora).

O empreendedorismo urbanoé a abordagem que atualmente orienta as gestões públicas e privadas para esse tipo de ação. Dentro da nova divisão internacional do trabalho aqui conceituada.

[...] o movimento rumo ao empreendedorismo tem desempenhado um importante papel facilitador na transição dos sistemas de produção fordistas localizacionalmente rígidos, suportados pela doutrina do bem-estar social keynesiano, para formas de acumulação flexível, muito mais abertas em termos geográficos e com base no mercado (Harvey, 2006, p. 181).

A governança urbana tenta combinar quatro estratégias que se tornaram fundamentais para as localidades enfrentarem o atual padrão de acumulação e competitividade (Harvey, 2006). A primeira delas já foi aqui mencionada e refere-se à criação de vantagens competitivas. Como também se viu, esses investimentos têm operado preponderantemente através de parcerias público-privadas e se traduzem, entre outros, em subsídios ou renúncias fiscais, recursos logísticos, crédito acessível e financiamento de pesquisas e qualificações que possam forjar as vantagens competitivas locacionais.

A segunda concerne ao incremento do mercado de consumo local, o que também tem a ver com o acesso ao crédito barato e, particularmente, com a gentrificação metropolitana, que tenta criar melhorias físicas, arquitetônicas e culturais de modo a gerar um ambiente urbano que possa passar a imagem de um lugar com boa qualidade de vida, cultural, dinâmico e inovador e, portanto, com potencial para absorver novos modos de consumo. $\mathrm{O}$ aquecimento da indústria do turismo nos 
últimos anos, por exemplo, tem se dado a partir desse tipo de ação. Já a terceira estratégia da governança urbana diz respeito às novas formas de buscar captação de recursos do governo federal, que cada vez mais passam por canais que colocam em concorrência Estados e municípios.

A quarta medida é aquela que aqui mais interessa, e tem a ver com a "[...] obtenção das atividades de controle e comando referentes às altas finanças, ao governo, à coleta de informações e ao seu processamento.” (Harvey, 2006, p. 177). Ou seja, atividades vinculadas aos serviços de apoio às transações financeiras, comerciais e produtivas das grandes empresas, que, além de exigirem uma infraestrutura tecnológica adequada à coleta e ao processamento eficiente de informações estratégicas, também requerem uma força de trabalho qualificada para atender a essas atividades específicas. Como tais investimentos compreendem um patamar intermediário de valor agregado nos seus processos, funções e equipamentos, requerem habilidades especializadas. É aqui que se abrem as brechas para a proliferação de instituições privadas de ensino superior que hoje assolam o panorama das cidades (Selari, 2009).

Nota-se, assim, todo um discurso oficial que parte do pressuposto de que a maior interconexão entre os mercados e, portanto, a cooperação coordenada de uma rede de empresas do mesmo setor podem atrair maiores investimentos e, desse modo, promover um incremento de sua cadeia produtiva. Segundo essa visão, os fluxos das redes formadas por tais empresas tenderiam a espraiar inovação em todos os pontos de suas cadeias de produção, gerando, com isso, o desenvolvimento das regiões e localidades que abrangem (Arranjo Produtivo Local, 2011). Assim, tais fluxos levariam progressivamente à distribuição de recursos às demais atividades interligadas, gerando um efeito multiplicador a toda população do entorno, uma vez que promovem a criação de novos empregos e renda, elevam a qualificação requerida e, com isso, incrementam os salários, o consumo e as condições de existência (Câmara; Campos; Sereia, 2009).

Atualmente, os Arranjos Produtivos Locais
(APLs) evidenciam-se como uma das principais políticas referentes a essa noção, pois tratam de estimular pequenas e microempresas a se constituírem como clusters que oportunizem a inclinação produtiva de uma dada região. Com isso, os APLs expressam uma concepção de desenvolvimento sustentável na qual o local passa a ser visto como um eixo articulador de agenciamento econômico e social (Antero, 2006). É desse modo que os APLs se reportam ao conceito de desenvolvimento local, governança e empreendedorismo urbano.

Contrariamente a essa perspectiva oficial, aventa-se aqui a hipótese de que os APLs tendem a alavancar esse desenvolvimento pela reiteração da precarização das relações de trabalho, açambarcadas nas cadeias produtivas das grandes corporações e favorecendo as pontas virtuosas (matrizes) dessas cadeias, em detrimento da valorização do emprego formalmente protegido presente nas suas "franjas". Com efeito, é essa hipótese que será desenvolvida a seguir.

\section{OS ELOS DA PRECARIZAÇÃO: políticas públicas de empreendedorismo e o caso do apl de TI de Londrina (PR)}

Como se viu, a concepção de desenvolvimento local emerge como uma nova agenda para responder aos efeitos sociais nefastos que as políticas neoliberais geraram, colocando-se, assim, como uma alternativa a essa via de desenvolvimento (Tapia, 2005). Ao contrário do modelo neoliberal, cujo enfoque parte do global, o foco do desenvolvimento local volta-se para o crescimento das localidades e, como também já foi visto, fundamentase na noção de vantagem competitiva, entendida como um "processo contínuo de inovação, crescimento e agregação de valor às atividades" produtivas regionalmente ambientadas (Dall'Acqua, 2003, p. 48, 50). Espera-se, assim, garantir um desenvolvimento sustentável, ou seja, capaz de dinamizar as economias locais de maneira autônoma, tornando-as menos sujeitas às dinâmicas predatórias da competitividade global. 
As políticas de empreendedorismo são tidas como a chave para a busca desse desenvolvimento local sustentável na medida em que preveem ações para empreendimentos que, embora pequenos, são suficientemente inovadores para "[...] gerar um alto impacto no crescimento econômico, movendo a economia para produtos e serviços com maior valor agregado.” (CEAPG/CENN, 2012, p. 12). A seleção de uma indústria nativa dominante é estratégia básica para se criar esse ambiente. Isso passa pela sua potencialidade de atrair investimentos privados de risco, venture capital, direcionados a iniciativas ainda em fase de consolidação, bem como incentivos públicos que possam contribuir para criar condições vantajosas a essa atratividade (2012).

Os Arranjos Produtivos Locais constituem uma ação que se integra a essa concepção de desenvolvimento, pois são considerados como uma política pública capaz de dinamizar as empresas de pequeno e microporte, valendo-se não só das propensões econômicas, mas também de políticas, sociais e culturais específicas ao "capital social" das localidades em que estão inseridas. O conceito de capital social foi emprestado das teorias sociológicas influenciadas pelo pensamento de Pierre Bourdieu e vem sendo usado pelas teorias econômicas referentes ao contexto neoliberal para invocar as "[...] características das organizações sociais tais como as redes, as normas e a confiança, que facilitam a coordenação e a cooperação em vista de um benefício mútuo" (Muls, 2008, p. 7). Segundo tais teorias, "[...] regiões que têm uma forte tradição de engajamento cívico (elevado estoque de capital social) conseguem acionar mecanismos que melhoram o desempenho das instituições e governos locais." (2008, p. 7).

Consoante o jargão presente nos discursos oficiais atrelados às atuais políticas de fomento ao empreendedorismo, é por intermédio do "capital social" local que se podem diligenciar "vantagens competitivas" que garantam um desenvolvimento econômico regional mais equilibrado e sustentável, portanto com maior possibilidade de geração de emprego e renda, o que incidiria na qualidade de vida das populações dos lugares em que ope- ram (DECOMTEC/FIESP, 2005).

Nesse sentido, a competitividade passaria a ter como principias fontes: 1) a "capacidade tecnológica” (que prevê uma inter-relação virtuosa entre ciência, tecnologia, gerência e qualificação); 2) o "acesso a um grande mercado afluente integrado" (que supõe a inserção geopolítica em zonas de comércio territorialmente definidas); 3) o "diferencial entre os custos de produção no local da produção e os preços do mercado de destino" (referente às regulamentações, legislação, direitos sociais e tributos regionais); 4) a "[...] capacidade política das instituições nacionais e supranacionais para impulsionar a estratégia de crescimento desses países ou regióes sob sua jurisdição, incluindo a criação de vantagens competitivas no mercado internacional para as empresas incluídas no rol das que servem aos interesses das populações de seus territórios, gerando emprego e renda" (Dall'Acqua, 2003, p. 51-52).

Nota-se que tais fontes têm um teor mais estratégico do que aquelas relativas às vantagens comparativas, as quais são dadas a priori e, portanto, necessitam do amparo de um Estado protecionista. Já o desenvolvimento das "vantagens comparativas" depende mais do engenho das administrações locais do que do suporte da Federação. São esses os princípios que fundamentam o conceito de desenvolvimento local que, por sua vez, orienta a constituição de um APL.

O termo "Tecnópolis" tem sido usado para ilustrar as cidades que optam por esse tipo de estratégia, de modo a "ressaltar novos cenários da inovação científica e tecnológica responsáveis pelo êxito de determinadas áreas ante outras, tais como o Vale do Silício (EUA)” (Pochmann, 2004, p. 42; Araki, 2000). Conforme Harvey (2006, p.177), a intenção é passar a imagem de uma "cidade do futuro", voltada para "[...] atividades de controle e comando, uma cidade informacional, pós-industrial, em que a exportação de serviços (financeiros, informacionais, produção de conhecimento) se torna a base econômica para a sobrevivência urbana."

Geralmente, os municípios que fazem esse tipo de opção são aqueles sem tradição industrial, 
voltados para atividades de apoio à economia agrícola, e que sofreram com a abertura comercial ao agronegócio. Sem indústria e com o declínio do setor agrário, tais municípios encontraram, no discurso do empreendedorismo urbano inspirado nas Tecnópolis, um caminho sedutor para o fomento do desenvolvimento local.

Os dados referentes ao APL de Tecnologia da Informação (TI) do município de Londrina confirmam essas análises. Desde a decadência da cafeicultura na região no final de década de 1970, as elites empresariais e os governos municipais vêm tentando forjar uma nova "vocação" para a cidade, como forma de atrair investimentos externos e, assim, alavancar a economia local. A partir da consideração de que Londrina é referência de fornecimento de serviços para o seu entorno regional, especialmente em educação, saúde e centros de P\&D (Ruiz; Uchoa Jr., Dinato, 2002), o empresariado regional e a administração pública, com o apoio das instituições de pesquisa locais, vêm, desde meados da década de 1990, apostando na estruturação de um polo tecnológico com vistas a fortalecer sua base empresarial relativamente recente e a granjear novos investimentos (Ruiz, 2011).

Em 1999, foi inaugurado o Projeto Tecnópolis (ADETEC, 2012), com a finalidade de promover "uma aproximação de ativos de inovação tecnológica com o setor produtivo” (Ruiz, 2011, p. 6). Por isso, o setor de TI foi reputado como estratégico para o desenvolvimento econômico da região. Foi com esse espírito que o APL de TI foi criado em novembro de 2006, "[...] com o objetivo de implementar ações comuns, que permitam a integração de empresas, o desenvolvimento de inovações tecnológicas e o acesso a novos negócios", bem como "demonstrar o potencial de crescimento da área de tecnologia da região, caracterizado essencialmente por pequenas empresas" (Arranjo Produtivo Local, 2011, grifo nosso).

No entanto, igualmente se constatou que esse crescimento não ocorre de forma independente do mercado global e das estratégias empresariais das grandes transnacionais. Com efeito, ele se dá dentro de uma rede que tem um centro assinalado pelo monopólio do mercado das ditas "inovações revolucionárias" e "radicais", isto é, aquelas que têm um impacto qualitativo tanto no mercado de consumo como no de bens de capital e, portanto, detêm o poder de redirecioná-los (Hirata; Zarifian, 1991). São empresas altamente intensivas no investimento em tecnologias de ponta, sendo, por isso, menos intensivas em trabalho vivo altamente qualificado. O papel estratégico dessa força de trabalho e a dificuldade em encontrar qualificações técnicas mais específicas aos seus copyrights system amenizam seus custos e explicam o motivo pelo qual ela reside, sobretudo, nos países centrais (Morris-Suzuki, 1997).

Por outro lado, no contexto da produção informatizada, o saber local exerce um papel estratégico fundamental, porque pode dar o diferencial necessário para o desenvolvimento daquilo que, no léxico empresarial, é chamado de "inovações incrementais" - relativas aos "resultados dos esforços cotidianos para aperfeiçoar produtos e processos existentes, visando obter maior qualidade e maior produtividade" (Fleury, 1993, p. 35). Essas inovações são conseguidas pela mediação dos softwares desenvolvidos pelas grandes transnacionais do setor, que desenvolvem e são detentoras dos referidos copyrights system. O direito de uso destes softwares é adquirido pelas intermediárias de suas cadeias de produção e adaptados para viabilizar a digitalização "dos caminhos pelos quais o trabalho pode ser feito de modo mais fácil e produtivo" (Morris-Suzuki, 1997, p. 16), o que incide diretamente na capacidade competitiva das empresas.

Como assinala Pochmann (2005), as cadeias produtivas se estruturam em dois planos hierarquicamente divididos: um relativo às atividades de concepção, planejamento e P\&D, geralmente localizado nos países centrais, e outro pela relocação, nos países periféricos, das atividades menos complexas dos seus processos. Segundo o autor, essa dinâmica tem levado a uma "periferização da indústria”, com consequências sobre as condições de trabalho daqueles trabalhadores que, inclusive, permanecem como formalizados nos processos de produção, pois: 
A mão de obra envolvida nesse processo assume menor custo do trabalho e as mais flexíveis e precárias condições de trabalho possíveis ao empregador [...]. As principais atividades laborais encontram-se concentradas nas esferas de execução, distribuição e montagem de produtos, muitas vezes, com organização do trabalho crescentemente taylorizada (Pochmann, 2005, p. 33).

Dessa forma, a distribuição e os benefícios, nas empresas de uma mesma cadeia produtiva, não serão iguais, na medida em que, por essa lógica, a razão de ser dessas pequenas e médias empresas é o seu cume. É isso que leva Bernardo (2004, p. 118) a afirmar que, na realidade, seus elos intermediários (fornecedores, subcontratados, montadoras, distribuidores e serviços terceirizados) são gestados como se fossem filiais: “[...] em termos de propriedade, são pequenas empresas locais, mas, por outro lado, graças à sua capacidade de integração tecnológica e de centralização administrativa, são grandes empresas transnacionais." Portanto, a reestruturação econômica neoliberal reorganizou as cadeias produtivas de um modo que dissimula uma complexa diversidade de novas formas de assalariamento, as quais conjugam e reequacionam os meios de extração de mais-valia relativa e absoluta, à semelhança do sistema de putting-out-system prevalecente nos primórdios do capitalismo (Bernardo, 2004).

Já estão por demais evidenciadas as pesquisas que demonstram que esses processos são medidas para reduzir os custos trabalhistas, bem como para promover a precarização dos contratos, condições e relações laborais que resulta dessa conjuntura (Druck, 2011; Marcelino, 2008; Krein, 2007). Éatravés desses processos que ocorre a desregulamentação do mercado de trabalho, com a aplicação de estratégias de flexibilização dos contratos trabalhistas, o que têm inflado significativamente informalidade, ampliado o desemprego real, além Gráfico 1 - Vínculos empregatícios nos segmentos do setor

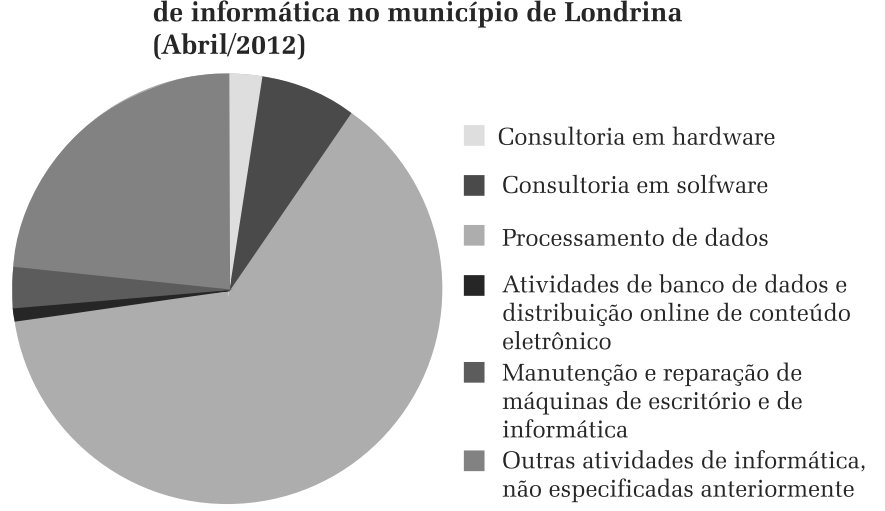
Fonte: CAGED - Ministério do Trabalho e Emprego. Elaboração GENTT de ensejar modelos de gestão que oportunizam processos espúrios de terceirização e subcontratação nos elos intermediários das cadeias produtivas das grandes corporações privadas (Krein, 2007). Assim se entende o vertiginoso crescimento das pequenas e microempresas no capitalismo contemporâneo.

Os dados referentes às empresas presentes no APL de Tecnologia da Informação (TI) de Londrina, apresentados nesta seção, confirmam essas análises. As variáveis delimitadas para análise foram: vínculos empregatícios formais e salário por segmento, demissão e rotatividade, escolaridade. Os dados foram coletados no período de Março e Junho de 2012, através do site do Ministério do Trabalho e Emprego (RAIS/CAGED). ${ }^{5}$ Os resultados permitem identificar que a perspectiva empreendedora que vem norteando essas ações acaba por esconder processos de precarização do trabalho, uma vez que aportam preponderantemente as atividades mais rotineiras presentes nas cadeias de suprimentos das grandes corporações.

Atualmente, esse APL constitui-se de 110 empresas regionais, entre micro e pequenas, 23 delas estabelecidas em Londrina. Seus segmentos básicos são: consultoria em hardware; desenvolvimento de software; processamento de dados; atividades de banco de dados e distribuição on-line de conteúdo eletrônico; e manutenção e reparação mais de 65 subsetores, dos quais 11 são exportados (Arranjo Produtivo Local, [20-]). de maquinário informático. Elas se ramificam em 
Nota-se, que, desde a implantação do APL de TI, também houve um aumento considerável de microempresas no aglomerado produtivo, isto é, daquelas que operam com até 10 empregados, surpreendendo o grande aumento relativo de "empresas" sem nenhum vínculo empregatício, tal como se pode confirmar pelos Gráficos apresentados a seguir.

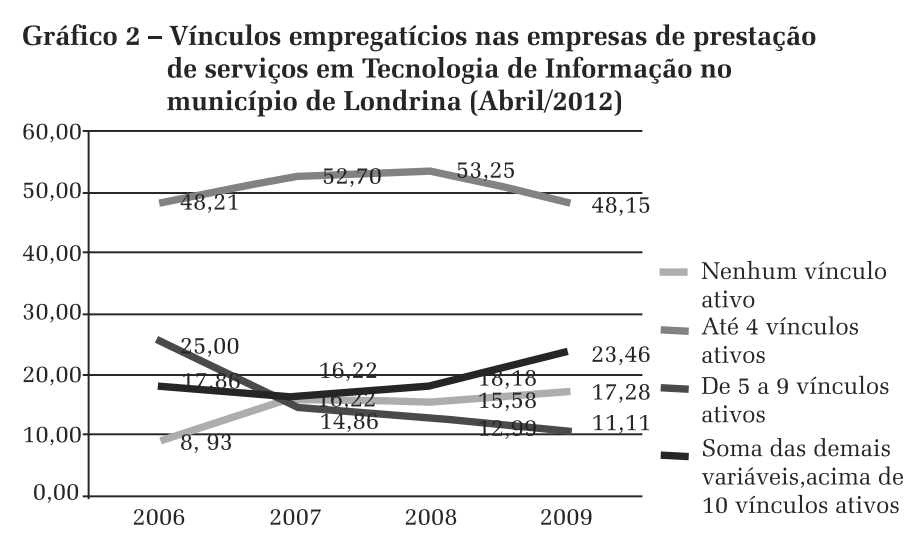

Fonte: RAIS - Ministério do Trabalho e Emprego. Elaboração GENTT

Gráfico 3 - Vínculos empregatícios em outras atividades de prestação de serviços em Informação no município de Londrina (Abril/2012)

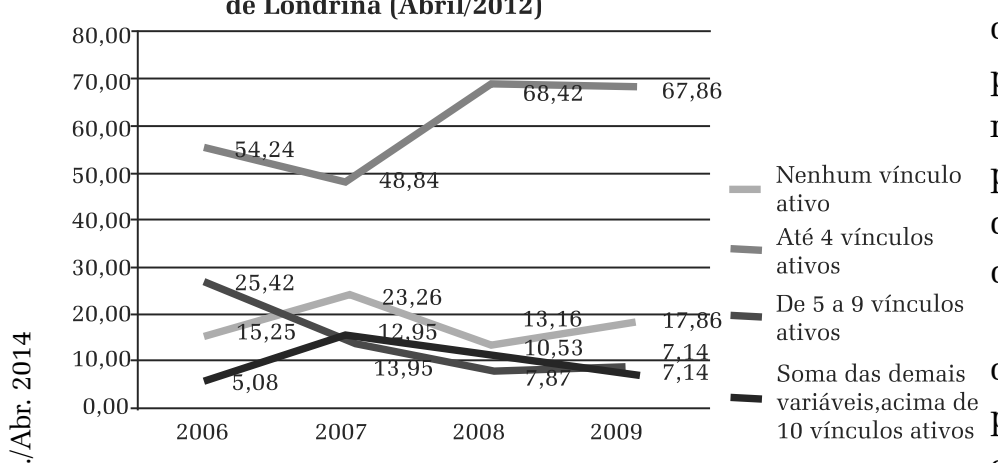

Fonte: RAIS - Ministério do Trabalho e Emprego. Elaboração GENTT

Gráfico 4 - Vínculos empregatícios nas empresas de prestação de serviços em tratamento de dados, hospedagem na internet e outras atividades relacionadas no município de Londrina (Abril/2012)

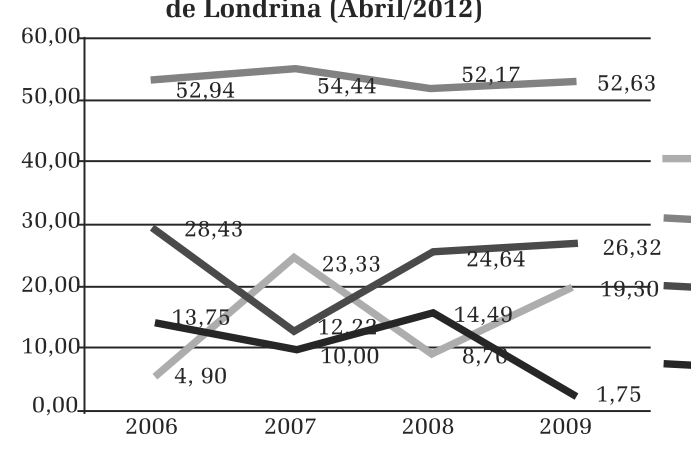

Fonte: RAIS - Ministério do Trabalho e Emprego. Elaboração GENTT
Percebe-se que a grande maioria das empresas do setor no município, 63,4\% (Gráfico 1), é relativa a atividades que se colocam nas "franjas" das cadeias produtivas de TI, ou seja, aquelas concernentes ao processamento e organização de dados, consultoria em software, distribuição online de conteúdo eletrônico e outras atividades de informática. Por conseguinte, referem-se às empresas cuja força de trabalho empregada, 93,78\% pela somatória de todas as atividades apresentadas, é a mais barata dentro das categorias profissionais existentes no setor, com uma média salarial que vai de 0,51 a um salário mínimo, com exceção da atividade de consultoria em software, que tem uma média salarial de dois a três salários mínimos, como pode ser verificado nos gráficos 5,6 e 7 .

No Gráfico 8, é possível observar que apenas o conjunto da força de trabalho inserida na faixa salarial que vai de dois a três salários mínimos, isto é, consultoria em software e hardware, possui ensino superior completo. No restante, prevalece o ensino médio completo, o que é um indicativo de baixa qualificação e explica a predominância dos baixos salários.

Na legenda desse ultimo gráfico, "Analfabeto" e "Ensino Médio completo" estão praticamente da mesma cor... É assim mesmo? Além disso, a parte inferior das colunas está truncada.

Outra variável que demonstra, de maneira mais qualitativa, a precarização do trabalho no setor de TI em Londrina é o alto grau de rotatividade de sua força de trabalho. Estudos demonstram que essa questão tem relação direta tanto com a sazonalidade derivada de alguns setores, tal como o de confecções (Silva, 2009; Jinkings; Amorim, 2006), bem como com as condições de trabalho próprias de trabalhos rotineiros e pouco criativos, que requerembaixa qualificação(Antunes;Braga, 
Gráfico 5 - Média salarial dos empregados vinculados a atividade de processamento de dados no município de Londrina (Março/2012)

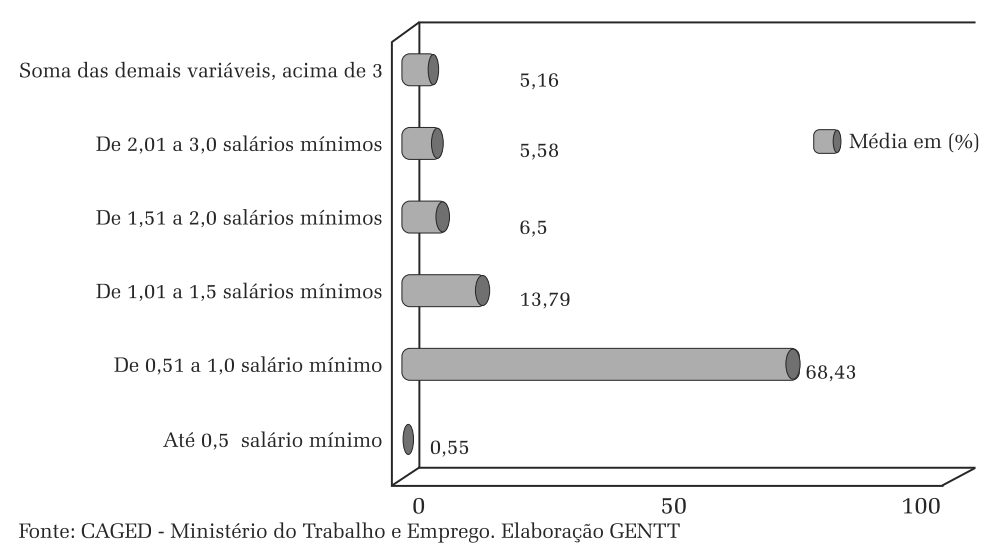

Gráfico 6 - Média salarial dos empregados vinculados a outras atividades de informática no município de Londrina (Março/2012)

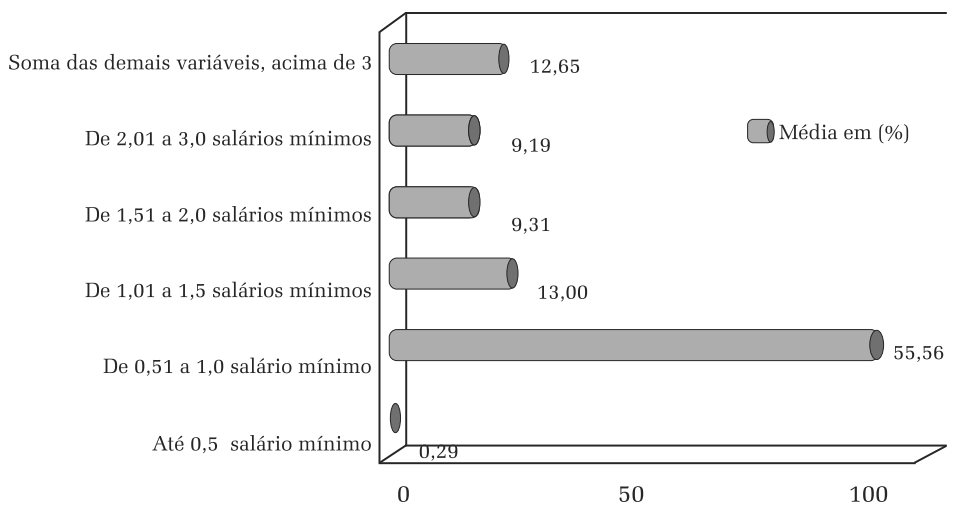

Fonte: CAGED - Ministério do Trabalho e Emprego. Elaboração GENTT

Gráfico 7 - Média salarial dos empregados vinculados a atividade de consultoria em software no município de Londrina (Março/2012)

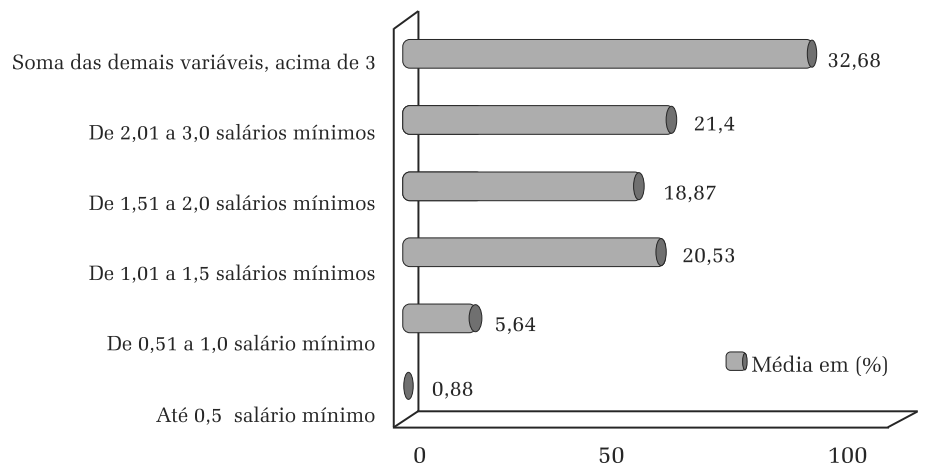

Fonte: CAGED - Ministério do Trabalho e Emprego. Elaboração GENTT

2009). De acordo com o Cadastro Geral de Empregados e Desempregados (CAGED), Gráfico 9, no setor de TI de Londrina ocorre uma grande rotatividade.
Como adverte Bernardo (2004), a rotativi-dade presente nos setores tecnologicamenteavançados evidencia a introdução da lógica da mais-valia absoluta em processos que tradicionalmente eram lócus de mais-valia relativa. Isso ocorre, sobretudo, em função da lógica dos copyright system, que, para manter sua clientela cativa, promove recorrentes atualizações visando a deixar o seu uso mais "amigável”. Com isso, igualmente, ocorre a simplificação do trabalho dos seus processos intermediários, tornando tais atividades dependentes e vulneráveis às qualificações fornecidas pelas empresas detentoras dessas patentes. Como a simplificação dos sistemas também simplifica as habilitações requeridas para sua operacionalização, diminui-se o tempo de capacitação, o que faculta às empresas usuárias demitir e empregar conforme a contingência de suas demandas.

Consequentemente, esse quadro configura a mesma dinâmica da superexploração do trabalho, característica dos processos produtivos relativamente menos intensivos em tecnologia, espaço da maisvalia absoluta, e, para os ramos de alta densidade tecnológica, espaço da mais-valia relativa. Assim, a empregabilidade da força de trabalho vinculada às cadeias produtivas das grandes empresas produtoras de tecnologias avançadas se torna sujeitaàmesma degradaçãoeinstabilidade laboral presente nas atividades de baixo valor agregado. 


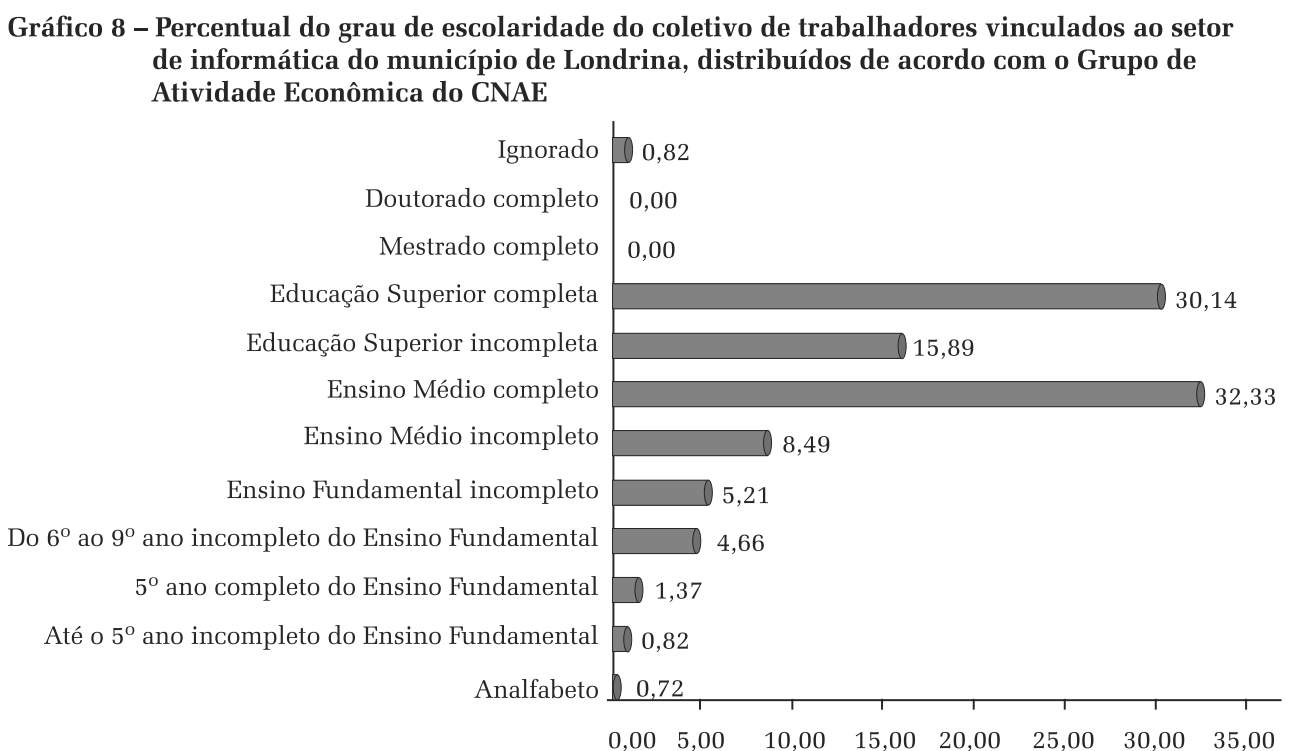

Fonte: Cadastro Geral de Empregados e Desempregados do Ministério do Trabalho e Emprego - CAGED (Junho/2012)

\begin{abstract}
conservam ou aumentam as qualificações da força de trabalho estável, o que a condena a deteriorar as suas capacidades e, portanto a conduz para tipos de empregos piores. Em conclusão, no processo de exploração a que está sujeita, essa força de trabalho, que embora precária era inicialmente qualificada, diminui a componente da maisvalia relativa e aumenta progressivamente a da mais-valia absoluta (Bernardo, 2004, p.131).
\end{abstract}

Tendo em vista que, com a globalização econômica, igualmente se constitui um mercado de trabalho global, essa evidente debilitação das condições de trabalho dos países periféricos acaba por se refletir sobre os trabalhadores situados nas nações centrais.

Gráfico 9 - Média de rotatividade empregatícia dos trabalhadores do setor de TI do município de Londrina (Junho/2012)

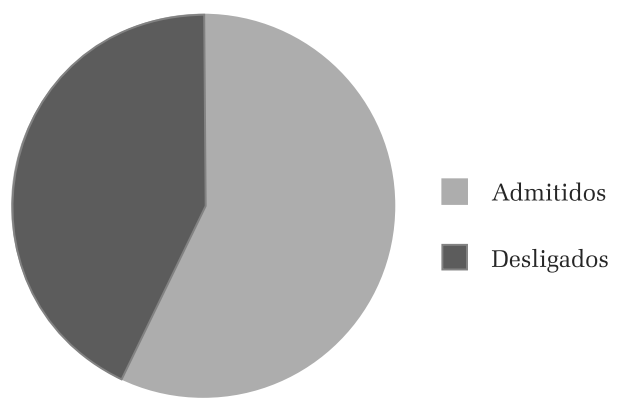

Fonte: CAGED - Ministério do Trabalho e Emprego.
Deste modo, ao mesmo tempo em que introduziu um novo estágio de mais-valia relativa [...] [tem-se] o aparecimento de certas modalidades de exploração, que, comparadas com os estágios anteriores, apresentam-se como mais-valia relativa, mas que, comparadas com a situação das empresas mais evoluídas do estágio atual, revelam-se como mais-valia absoluta. Tal como sempre tem sucedido, também hoje a mais-valia absoluta é o complemento necessário da mais-valia relativa (Bernardo, 2004, p.132).

Há de se considerar, ainda, que o novo formato da divisão internacional do trabalho e a reconjugação entre mais-valia absoluta e relativa que essa dinâmica implicou traz, em seu bojo, novas contradições, pois, ao integrar e incrementar novos mercados, tende não só a acirrar a competitividade entre os países, como, ao fazê-lo, saturar, mais cedo ou mais tarde, seus mercados internos de trabalho e consumo. Com isso, criam-se novos excedentes de capital e força de trabalho, o que pode levar a novas crises de sobreacumulação, tal qual a originariamente enfrentada pelos países de industrialização avançada.

Para os nossos propósitos, o que é importante ressaltar é que os rearranjos setoriais, constituídos no bojo da reestruturação e da flexibilização produtivas e trazidos pelo novo movimento de expansão capitalista, longe de dinamizarem as economias locais para a sua inserção autônoma e sustentável na 
economia globalizada, traduzem um novo modo de sua subordinação a esse processo. Reproduz-se, assim, em novas bases, a divisão internacional do trabalho, de modo desigual e mais conectado do que nunca. Em síntese, tem-se o resultado oposto ao esperado e apregoado pelo discurso e pelas ações ligadas às políticas públicas de cunho empreendedorista, cujo principal mote é blindar o local contra as intempéries do capital global.

\section{CONSIDERAÇÕES FINAIS}

Em que pese o risco da generalização e a necessidade de comparação com outras experiências nacionais e internacionais, projeto que já está no horizonte, o estudo aqui desenvolvido permitiu formular um percurso metodológico preliminar com o objetivo de fornecer parâmetros para análises que permitam avaliar em que medida as políticas públicas ancoradas nas concepções de desenvolvimento local, empreendedorismo e governança urbana vêm tendo êxito.

É certo que, na última década, os Arranjos Produtivos Locais passaram a ter uma especial relevância dentro dessas políticas, como uma aposta para dirimir as vulnerabilidades das economias locais face à transnacionalização do capital e à sua tendência à debilitação do mercado de trabalho. Viu-se, porém, que essa aposta esbarra nas estratégias das grandes corporações transnacionais que, ao externalizarem as "franjas" de suas cadeias produtivas no espaço dos mercados nacionais fornecedores de trabalho barato, forjam uma especialização forçada, voltada para as atividades de apoio a seus processos, produtos e comercialização. Com isso, inflaciona aquele setor que mais tem instigado formas de precarização das relações e condições laborais, o setor de serviços.

A análise do APL de TI de Londrina (PR) permitiu identificar o aumento do número de microempresas do setor, inclusive muitas sem nenhum vínculo empregatício, sendo a maior parte relativa a processos de parametrização e customização de produtos adquiridos das transnacionais do ramo.
O perfil preponderante da força de trabalho presente nessas firmas - baixo grau (relativo) de escolaridade, prevalecendo o ensino médio completo, faixa salarial que gira em torno de 0,5 a um salário mínimo, além do alto índice de rotatividade - remete a indicadores de precarização já consensuais na literatura especializada sobre o tema (Druck, 2011).

Assim, diferentemente da perspectiva ofici$\mathrm{al}$, os resultados demonstram que, no caso em questão, reitera-se, ao invés de dirimir, a precarização do mercado de trabalho, visto que as microempresas tendem a sediar os processos mais simples presentes nas cadeias de valor das corporações desenvolvedoras de tecnologias avançadas. Ou seja, justamente aquelas atividades que estão mais sujeitas às vulnerabilidades laborais postas pela mobilidade que o grande capital ganhou com a globalização da economia.

Isso ocorre porque a atual integração flexível das cadeias de produção, em sua articulação globallocal, exige não apenas uma reestruturação produtiva e nas relações de trabalho internas às empresas, mas também o remodelamento das bases sociais, econômicas, geográficas e institucionais que servem de suporte a essa integração. Em outras palavras, exige um arranjo que extrapole a esfera da produção e se estenda a toda a sociedade através de políticas específicas que incentivem e atendam ao novo padrão de acumulação e competição capitalista.

Faz-se necessário, ainda, observar em que medida as atuais políticas públicas de desenvolvimento orientadas pela abordagem empreendedora são efetivamente adotadas na totalidade dos processos de produção das empresas, ou seja, considerando todas as unidades ou atividades produtivas necessárias à produção e circulação de seu produto final; ou se apenas funcionam como um meio de angariar seus possíveis bônus, deixando os ônus a cargo dos trabalhadores forçadamente especializados e externalizados do seu nexo produtivo. É o que se aponta para a continuidade desta pesquisa.

Recebido para publicação em 20 de dezembro de 2012 Aceito em 24 de março de 2013 


\section{REFERÊNCIAS}

ADETEC - Associação do Desenvolvimento Tecnológico de Londrina e Região. Livro Londrina Tecnópolis. Disponível em http://adetec.org.br/site/?s=tecn\%C3\%B3polis\&search=Buscar. Acesso em: maio 2012.

ALVES, G.; WOLFF, S. Capitalismo global e o advento das empresas-rede: contradições do capital na quarta idade da máquina. Cadernos do CRH: revista do Centro de Recursos Humanos da UFBA, Salvador, v. 20, p. 515-528, 2008.

ANTERO, Samuel A. Articulação de políticas públicas a partir dos fóruns de competitividade setoriais: a experiência recente da cadeia produtiva têxtil e de confecções. Revista de Administração Pública - RAP, Rio de Janeiro, v. 1, n. 40, p. 57-80, jan./fev. 2006,

ARAKI, K. Technological innovation, national urban policy and local development: policy implications of the concept of technopole and Japan's Technopolis Programme for Developing Countries. August 2000. Disponível em: http:// www.bartlett.ucl.ac.uk/dpu/publications/latest/publications/ dpu-working-papers/wp110.pdf. Acesso em: jun. 2011.

BALTAR, R.; WOLFF, S. Trabalho decente e cadeias produtivas: uma análise da implementação de programas estaduais para promoção da agenda trabalho decente no Brasil. In: CONGRESSO BRASILEIRO DE SOCIOLOGIA, 14, Rio de Janeiro, 2009. Anais...

BERNADO, J. Democracia totalitária - teoria e prática da empresa soberana. São Paulo: Cortez, 2004.

BNDES. Banco de Desenvolvimento Econômico e Social. Arranjos produtivos locais e desenvolvimento. Rio de Janeiro: Área de Planejamento e DEPRO, 2004.

BRASIL. Ministério do Trabalho e Emprego. Cadastro Geral de Empregados e Desempregados - CAGED. Brasília: MTE, 2009a. Disponível em: http://www.mte.gov.br/caged/ default.asp. Acesso em: nov. 2011.

. Ministério do Trabalho e Emprego. Relação Anual de Informações Sociais - RAIS. Brasília: MTE, 2009b. Disponível em: http://www.mte.gov.br/rais/default.asp. Acesso em: nov. 2009.

BRASIL. Site do Governo brasileiro. Social Development/ Local Production Arrangements. Disponível em: http:/ www.brasil.gov.br/sobre/science-and-technology/socialdevelopment/. Acesso em: jul. 2012.

CAIADO, S. C.; RIBEIRO, T. F. F.; AMORIM, R. L. C. Políticas neoliberais e reestruturação produtiva. In POCHMANN, Marcio (Org.). Reestruturação produtiva: - perspectivas de desenvolvimento local com inclusão soฮ cial. Rio de Janeiro: Vozes, 2004.
CÂMARA, M. R. G.; CAMPOS, Maria F. S.; SEREIA, V. J. (Org.). Características e potencialidades das aglomerações de software no Paraná. Londrina: EDUEL, 2009.

CAMARGO, J. M. Reforma da legislação trabalhista. IN: CARDOSO, et al. Sindicalismo e relações trabalhistas. Rio de Janeiro: Fundação Konrad Adenauer, 2002. p. 51-67.

CAMPOS, A. C. de; PAULA, N. M. Do aglomerado industrial ao APL: uma análise da indústria de confecções de neiro, v. 7, n. 1, p. 147-176, jan./jun., 2008.

CARDOSO, A. M. Reforma econômica, competitividade e relações industriais no Brasil: estudos de caso nos setores automobilístico e têxtil. Revista Latinoamericana de Estudios del Trabajo, São Paulo, v. 5, n. 9, p. 51-83, 1999.

et al. Sindicalismo e relações trabalhistas. Rio de Janeiro: Fundação Konrad Adenauer, 2002. p. 69-89.

CASTILLO, J. J. Las fábricas de software en España. Cianorte (PR). Revista Brasileira de Inovação. Rio de Ja-
Organización y división del trabajo: el trabajo fluido em la sociedad de la información. Política \& Sociedade: revista de Sociologia Política, Florianópolis, v. 7, n. 3, p. 35-108, out. 2008. Tradução livre.

CEAPG/CENN. Centro de Estudos em Administração Pública e Governo/Centro de Empreendedorismo e Novos Negócios. Desenvolvimento de políticas públicas de fomento ao empreendedorismo em Estados e Municípios. São Paulo: Programa Gestão Pública e Cidadania, 2012. Disponível em: http://www.eaesp.fgvsp.br/subportais/ ceapg/Arquivos/POLITICAS_PUBLICAS _site.pdf. Acesso em: jun. 2012.

DALL'ACQUA, C. T. B. Competitividade e participação: cadeias produtivas e a definição dos espaços econômicos, global e local. São Paulo: Annablume, 2003.

DECOMTEC/FIESP. Experiência dos APLs da FIESP. São Paulo: FIESP, 2005. Disponível em: http:// www.fiesp.com.br/competitividade/downloads/apl.pdf. Acesso em: maio 2011.

DE SENA, A. Micro-empresas, microemprendimientos, emprendimentos productivos. De que hablamos? Política \& Trabalho, João Pessoa, UFPb, v. 27, n. 32, p. 75-92, 2010.

DRUCK, G. Trabalho, precarização e resistências: novos e velhos desafios? Caderno CRH: revista do Centro de Recursos Humanos da UFBA, Salvador, v. 24, n.esp. 1, p. 35-55, 2011.

FIORI, J. L. Brasil no espaço. Petrópolis: Vozes, 2001.

FLEURY, A. Novas Tecnologias, capacitação tecnológica e processo de trabalho. In: HIRATA, H. (Org.) Sobre o modelo japonês. São Paulo: EDUSP, 1993.

FUINI, L. L. A nova dimensão da competitividade: territorialização e arranjos produtivos locais (APL). Caminhos de Geografia, Uberlândia,MG, v. 9, n. 25, p. 148157, mar. 2008.

HARVEY, D. A produção capitalista do espaço. São Paulo: Annablume, 2006.

O "novo" imperialismo: sobre rearranjos espaciotemporais e acumulação mediante despossessão. Margem Esquerda: ensaios marxistas, São Paulo, Boitempo Editorial, n.5, p.31-40, maio 2005a.

O novo imperialismo. São Paulo: Loyola, 2005b.

HIRATA, H.; ZARIFIAN, P. Força e fragilidade do modelo japonês. Estudos Avançados, São Paulo, v.5, n.12, p.173$185,1991$.

INSTITUTO DE DESENVOLVIMENTO DE LONDRINA (CODEL). Disponível em: http:// www.codel.londrina.pr.gov.br/. Acesso em: mar. 2011.

. Micro empreendedor individual. Disponível em: http://www2.londrinapr.gov.br/codel/ index.php/micro-epequenas-empresas/micro-empreendedor-individual. Acesso em: mar. 2011.

Cadernos Setoriais. Disponível em: http:// www.codel.londrina.pr.gov.br/geral/geral cadernos.asp. Acesso em: mar. 2011.

GOMES, K. M.; GALON, E.; LOPES, S. L.; JARDINETTE, E. Mercado de trabalho e qualificação. Cadernos Setoriais: Instituto de Desenvolvimento de Londrina, 2004.

JINKINGS, Isabella; AMORIM, Elaine R. A. Produção e desregulamentação na indústria têxtil e de confecção. In: ANTUNES, Ricardo (Org.). Riqueza e miséria do trabaIho no Brasil. São Paulo: Boitempo, 2006. p.337-385.

KREIN, J. D. Tendências recentes nas relações de emprego no Brasil: 1990-2005. 2007. Tese (Doutorado em Economia Social e do Trabalho) - Universidade Estadual de Campinas, 2007. 

LONDRINA. Prefeitura Municipal, http://
www1.londrina.pr.gov.br/. Acesso em mar, 2011.

Sala do Empreendedor. Disponível em: http:// www2.Iondrina.pr.gov.br/codel/index.php/ micro-e-pequenas-empresas/sala-do-empreendedor. Acesso: abr. 2012.

MARCELINO, P. R. P. Terceirização e ação sindical: a singularidade da reestruturação do capital no Brasil. 2008. Tese (Doutorado em Ciências Sociais) - Universidade Estadual de Campinas. 2008.

MDIC. Ministério do Desenvolvimento, Indústria e Comércio Exterior. Disponível em: http://www. mdic.gov.br/ sitio/interna/interna.php?area $=2 \&$ menu $=300$ Acesso em: jan. 2012.

MORRIS-SUZUKI, T. Robots and Capitalism. In: DAVIS J.; HIRSCHL, T.; STACK, M. (Org.) Cutting edge: technology, information capitalism and social revolution. London/New York: Verso, 1997.

MULS, L. M. Desenvolvimento local, espaço e território: o conceito de Capital Social e a importância da formação de redes entre organismos e instituições. Revista Economia: revista da ANPEC, Brasília, v.9, n.1, p.1-21, jan/abr de 2008. Disponível em: http://www.anpec.org.br/revista/vol9/vol9n1p1_21.pdf. Acesso: maio 2011.

ORGANIZAÇÃO INTERNACIONAL DO TRABALHO (OIT). Secretaria Internacional do Trabalho Brasil. Trabalho decente nas Américas: uma agenda hemisférica, 20062015. Informe do diretor geral. In: REUNIÃO REGIONAL AMERICANA,16., 2006, Brasília.

POCHMANN, M. Nova Classe Média? O trabalho na base da pirâmide social brasileira. São Paulo: Boitempo, 2012.

O emprego na globalização: a nova divisão internacional do trabalho e os caminhos que o Brasil escolheu. São Paulo: Boitempo, 2005.

Desenvolvimento capitalista e divisão do trabaho. In: POCHMANN, M. (Org.) Reestruturação produtiva: perspectivas de desenvolvimento local com inclusão social. Petrópolis: Vozes, 2004.
PORTAL DO EMPREENDEDOR INDIVIDUAL PELO MINISTÉRIO DO DESENVOLVIMENTO, INDÚSTRIA E COMÉRCIO EXTERIOR - MDIC. Disponível em http:// www.portaldo empreendedor.gov.br/modulos/inicio/ index.htm. Acesso em: jun. 2012.

SOUZA e SILVA, J.; BARBOSA, J. L. O sentido do trabalho informal na construção de alternativas socioeconômicas e o seu perfil no Rio de Janeiro. In: CENTRO DE ESTUDOS E ACÕES SOLIDÁRIAS DA MARE, SEBRAE; OBSERVATÓRIO DE FAVELAS DO RIO DE JANEIRO. (Org.). As empresas da Maré - Dados do Censo Maré 2000. Rio de Janeiro: 2004. p.5-15.

SELARI, L. Qualificação, competência e a comodificação da educacão: o crescimento do ensino superior em Londrina-Pr. TCC - Universidade Estadual de Londrina-UEL, 2009.

SILVA, C. X. Nos "fios invisíveis" da terceirização: a precarização do trabalho na indústria de confecções. TCC - Universidade Estadual de Londrina, 2009.

SILVER, B. Forcas do trabalho: movimentos de trabalhadores e globalização desde 1870. São Paulo: Boitempo, 2005

TAPIA, J. R. B. Desenvolvimento local, concertação social e governança: a experiência dos pactos territoriais na Itália. São Paulo em Perspectiva, São Paulo, v.19, n.1, p.132139, jan/mar. de 2005. Disponível em: http:// www.scielo.br/pdf/spp/v19n1/v19n1a12.pdf. Acesso em: maio 2011

TELLES, V. Transitando na linha da sombra, tecendo as tramas da cidade (anotações inconclusas de uma pesquisa). In: OLIVEIRA, Francisco; RIZEK, Cibele (Org.) A era da indeterminação. São Paulo: Boitempo, 2007.

WACQUANT, L. Ressituando a gentrificação: a classe popular, a ciência e o Estado na pesquisa urbana recente. Caderno CRH: revista do Centro de Recursos Humanos da UFBA, Salvador, v.23, n. 58, p. 51-58, jan./abr. 2010. 


\section{LOCAL DEVELOPMENT, ENTREPREUNERISM AND URBAN "GOVERNANCE": where is labor inserted within this context?}

\section{Simone Wolff}

This paper questions three concepts of public policies presented nowadays as alternatives to the neoliberal economic paradigm and to the precarization of the labor market that has come in its wake: local development, entrepreneurism and urban governance. As their object are the companies that form the Productive Local Arrangement of Information Technology in the region of Londrina, Paraná, inserted within the public policies here problematized. Data collected from the Ministry of Labor and Employment (MTE) show that these companies tend to provide the routine activities present in the chains of value of the sector's large transnational corporations, which are more susceptible to the labor vulnerabilities imposed by the mobility that capital has acquired with economic globalization. Thus, different from the official perspective that guides these policies, the results refer to precarization indicators that are a consensus in specialized literature on the topic: lower schooling grade, salaries around 0.5 to one minimum wage and high turnover level.

KEY WORDS: Local Development. Entrepreneurism. Urban governance. Local productive arrangements. Labor precarization.

\section{DÉVELOPPEMENT LOCAL, ENTREPRENEURIAT ET “GOUVERNANCE” URBAINE: quelle est la place du travail dans ce contexte?}

\section{Simone Wolff}

On s'interroge sur trois conceptions de politiques publiques présentées aujourd'hui comme des propositions alternatives pour le paradigme économique néo-libéral et la précarisation du marché du travail qui l'a accompagné: le développement local, l'entrepreuneuriat et la gouvernance urbaine ayant pour objet les entreprises qui font partie de l'Arrangement Productif Local de Technologie de l'Information de la Région de Londrina (PR), et qui s'insère dans les politiques publiques ici problématisées. Les données recueillies auprès du MTE démontrent que les entreprises ont tendance à faire l'apport des activités courantes présentes dans les chaînes de valeur des grandes entreprises transnationales du secteur, qu'elles sont plus sujettes aux vulnérabilités de la main-d'œuvre à cause de la mobilité du capital due à la mondialisation de l'économie. Ainsi, à l'oposé de la perspective officielle qui oriente ces politiques, les résultats renvoient à des indicateurs de précarisation, fruits d'un consensus dans la littérature spécialisée sur le sujet: bas niveau (relatif) de scolarité, salaires d'environ 0,5 à 1 salaire minimum et un indice de rotativité très élevé.

Mots-CLÉs: Développement local. Entreprenariat. Gouvernance urbaine. Arrangements Productifs Locaux. Précarisation du travail.

Simone Wolff - Doutora em Ciências Sociais pela Universidade Estadual de Campinas - UNICAMP. Docente do Departamento e do Programa de Pós-Graduação em Ciências Sociais da Universidade Estadual de Londrina - UEL. Líder do Grupo de Estudos de Novas Tecnologias e Trabalho - GENTT/CNPq. Entre suas principais publicações destacam-se o livro Informatização do Trabalho e Reificação: uma análise à luz dos Programas de Qualidade Total (2005), publicado pela Editora da UNICAMP em co-edição com a EDUEL, além de capítulos nos livros Infoproletários (2009) e Riqueza e Miséria do Trabalho no Brasil (2006), ambos publicados pela Editora Boitempo. 